\title{
Use of a card game tool to capture end users' preferences and add sustainability value to social housing projects
}

\author{
Uso de jogo de cartas para capturar preferências de \\ usuários finais e agregar valor de sustentabilidade a \\ empreendimentos de habitação social
}

\section{Adrieli Cristina Vieira de Carvalho Ariovaldo Denis Granja Vanessa Gomes da Silva}

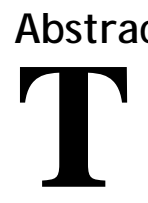
T the aspired sustainability values in housing projects based on the concept of stated preferences. A card game tool was developed based on the AQUA $\mathrm{HQE}^{\mathrm{TM}}$ rating system and applied to ask a 164-respondent sample, assembled from four social housing projects to identify their preferences regarding sustainable construction. Responses were statistically analyzed based on bootstrap confidence values and on the index of general significance (IGS) of each sustainable value attribute. Results show a sustainable value hierarchy, in which the health and safety parameters were the most valued. This study confirms the validity of using a set of illustrated cards as a potential tool for identifying sustainability values end users bear and consequently improving decision-making process within sustainable products development.

Keywords: Sustainable value. User value. Stated preferences. AQUA - HQETM rating system. Target costing. Cost reallocation.

\section{Resumo}

A indústria da construção está adotando cada vez mais estratégias sustentáveis para reduzir seus impactos ambientais. Apesar disso, algumas barreiras ainda são percebidas no mercado imobiliário de edifícios sustentáveis. Uma delas refere-se à entrega de produtos desalinhados das necessidades e valores dos usuários finais. Este artigo investiga os valores sustentáveis desejáveis para empreendimentos habitacionais, identificando as preferências declaradas pelos usuários finais com base na certificação

${ }^{1}$ Adrieli Cristina Vieira de Carvalho ${ }^{1}$ Universidade Estadual de Campinas Barão Geraldo Campinas - SP - Brasil

${ }^{2}$ Ariovaldo Denis Granja 2 Universidade Estadual de Campinas Barão Geraldo Campinas - SP - Brasil

${ }^{3}$ Vanessa Gomes da Silva ${ }^{3}$ Universidade Estadual de Campinas Barão Geraldo Campinas - SP - Brasil

Recebido em 25/03/19 Aceito em 17/07/19
AQUA- HQE ${ }^{\mathrm{TM}}$. O método de pesquisa foi baseado no conceito de preferência declarada. Para este fim, uma ferramenta na forma de jogo de cartas foi desenvolvida e aplicada para coletar as preferências de 164 entrevistados em relação à construção sustentável. Os dados foram analisados estatisticamente com base nos valores de confiança de "bootstrap", e no índice de importância geral (IGI) criado para cada atributo de valor sustentável. Constatou-se uma hierarquia de valor de sustentabilidade, encabeçada pelos parâmetros relacionados à saúde e à segurança. Esse estudo confirma o potencial da ferramenta utilizada para a identificação de valores referentes à sustentabilidade e à consequente melhoria do processo de tomada de decisão no desenvolvimento de produtos.

Palavras-chave: Valor sustentável. Valor do usuário. Preferência declarada. certificação AQUA- HQE ${ }^{\mathrm{TM}}$. Custeio-meta. Realocação de custos. 


\section{Introduction}

Sustainability issues have been extensively studied since the Brundtland report introduced the concept of sustainable development (WORLD..., 1987). This concept is an alert to ensure that actions and decisions presently taken for economic and social development do not affect the needs of future generations , 1987). Since then, numerous investigations in the construction industry have been conducted to reduce the impact of buildings on the natural environment.

Environmental impacts of the construction industry become a key subject and include problems that go well beyond the waste generated and the greenhouse gases emitted. The world's construction industry consumes $12 \%$ of drinking water and a third of the planet's natural resources (UNITED..., 2009). Residential and commercial buildings account for $20 \%$ to $40 \%$ of energy consumption in developed countries (PÉREZLOMBARD; ORTIZ; POUT, 2008). In Brazil, the sector represents $48.5 \%$ of the country's electricity consumption (SUSTAINABLE..., 2015).

But the construction industry also has a vital contribution to the development of societies. The challenge posed for sustainable construction is therefore to reconcile the benefits and impacts of construction activities (HAYLES, 2004). Sustainable construction implies meeting the end users' values with minimal environmental impact and within the financial scope. Previous researches have mostly focused on reducing waste and minimizing the carbon footprint (NOVAK, 2012), and on identifying users' satisfaction (THOMSON et al., 2003; RUIZ; GRANJA; KOWALTOWSKI, 2014; SPITEN et al., 2016). Design practice tools and methods are needed to enable designers to enhancing value creation (BOZTEPE, 2007a). Also, little information is available on how users relate to these new sustainable solutions and on how to understand what their priorities and desires are.

One way to improve the value perception in buildings and to increase sustainability efficiency is through value management (VM) (KELLY; MALE; GRAHAM, 2014). VM is a structured approach to establish what value means to a client in meeting a perceived need by defining and agreeing with the project objectives and establishing how they can be best achieved (CONNAUGHTON; GREEN, 1996). Sustainable values should be identified and aligned to the end users' desires to deliver an integrated outcome. However, this subject has not been extensively covered in the literature. Some studies already identified the VM's potential to achieve sustainable goals. For example, Abidin and Pasquire (2005) showed that VM could deliver sustainability at the early construction stage but there are gaps in current practices, indicating opportunities for improvement. More recently, Manoliadis (2012) identified the potential of VM for delivering sustainable construction projects in Greece through interviews with experienced project stakeholders. Nevertheless, this idea has not yet been widely put into practice.

Although the concern with sustainable strategies has increased, little attention has been paid to the identification of the desired values regarding sustainability, resulting in a gap between user's aspirations and sustainable buildings delivery. This gap reinforces yet another problem, i.e. "the vicious circle of blame" (KEEPING, 2000), where investors, occupants, contractors and developers blame each other in a loop for their own lack of commitment to adopt more sustainable real estate practices. This research aims at identifying social housing projects (SHP) end users stated preferences regarding sustainable building, based on the HighQuality Environment Certification (AQUA - HQE ${ }^{\mathrm{TM}}$ ) rating system. Specifically, its objective is to develop and test the suitability of an illustrated (game) cards tool to capture the end user sustainable desired values.

This paper is divided into two parts. The first part introduces the terminology related to the concept of value and sustainable value, and the literature findings concerning sustainability integration within VM. The second part presents the method, which was based on the model of stated preference, and the findings from a case study with end users in the region of Campinas, in the State of São Paulo, Brazil. This case study investigates the sustainable desirable values by identifying end users' stated preferences based on AQUA - HQE ${ }^{\mathrm{TM}}$ rating system. In the end, the results are presented, and some light is shed on the potential use of sets of illustrated cards to assess the delivery of sustainable building projects.

\section{The concepts of value and sustainable value}

The concept of value appears in the literature with different meanings according to the context (WOODRUFF, 1997). For economists, the concept of value of a product is represented by price and is related to the utility and satisfaction that the product causes (RICHINS, 1994). In marketing, however, purely economic considerations are not sufficient: value confronts perceptions and choices and is perceived as the trade-off between the benefits received by the product or service and the perceived sacrifices arising from the acquisition 
and use of this product (SALIBA; FISHER, 2000). In addition, value also receives the influence of psychology and sociology by incorporating behavioral aspects (IKEDA; VELUDO-DE-OLIVEIRA, 2005). In this case, the concept of value is studied considering the behavior of users, seeking to understand the relationship between personal values and the way of valuing products.

Despite efforts to define a single concept, a universal theory about the concept of value has not yet reached consensus in the literature (SALVATIERRA-GARRIDO; PASQUIRE; THORPE, 2010). However, the simplest definition of value is the cost-benefit relationship (SPITEN et al., 2016). In other words, value is the relationship between the satisfaction of needs and the resources to fulfil them. These needs, or benefits expected by clients, can be extensive, as each client has different perceptions and interests (MIRON, 2008). The big challenge for designers to create suitable design solutions is to incorporate and translate these perceptions and user values into housing design.

In recent years, there has been increased interest in the integration of values in the design process (BENEDIKT, 2008; BOZTEPE, 2007b; CARMONA, 2001; JENSEN; MASLESA, 2015; MACMILLAN, 2006; SAXON, 2005). This is a result of the growing recognition of value creation as an important factor in quality design for end users (MOGHIMI; JUSAN; IZADPANAHI, 2016). Efforts to increase value in housing can be seen in Benedikt (2008) and Lima et al. (2009), where they expand and adapt the needs presented by Abraham Maslow (1998) ${ }^{1}$ in the hierarchy of needs theory, with a specific focus on architecture. According to Benedikt (2008) value in architecture goes beyond the minimum inclusion of needs, i.e., values should incorporate needs on the highest degree of satisfaction. Carmona (2001), presents design considerations ranging from spatial, morphological, contextual, visual, perceptual, social, functional and sustainable concerns. Hershberger (1999) shows how to accurately assess the client's needs, tastes, and goals, and expended the traditional principles of architecture proposed by Vitruvius ${ }^{2}$ to eight value areas:

(a) human: functional, social, physical, physiological and psychological;

(b) environmental: site, climate, context, resources and waste;

(c) cultural: historical, institutional, political and legal;

(d) technological: materials, systems and processes;

(e) temporal: growth, change and permanence;

(f) economic: finance, construction, operation, maintenance and energy;

(g) aesthetic: form, space, color and meaning; and

(h) safety: structural, fire, chemical, personal and criminal.

Additional research have investigated the potential of the concept of value for improving the design process of social housing. Lima et al. (2009) have discussed the relationship among satisfaction, human needs and perceived value according to the perception of the clients, using a set of case studies. Granja et al. (2009) and Kowaltowski and Granja (2011) have investigated the use of the concept of desired value for improving social housing projects. With similar goal, Conceição, Imai and Urbano (2015) have related the requirements for housing according to the value desired according to the perception of users. Moraes (2017) have identified cost reallocation opportunities in order to increase value delivery, according to the user's perception of desired value. Some of these studies have also identified environmental values, which in this research will be related to the concept of sustainable value. As a matter of fact, the concept of sustainable value goes beyond environmental aspects and involves social and economic concerns.

From the sustainability perspective, value seems well accepted and disseminated in some sectors, such as manufacturing and automotive, where it is possible to identify the attempt to incorporate sustainability as an organizational value. However, it is difficult to find a consolidated and widespread definition for sustainable value applied to the construction industry, although several authors stress the importance of identifying and delivering sustainable values (ABIDIN; PASQUIRE, 2005; AL-YAMI; PRICE, 2005; HAYLES, 2004; KARUNASENA; RATHNAYAKE; SENARATHNE, 2016; PASQUIRE; SALVATIERRA-GARRIDO, 2011). Despite this, in its broadest sense, sustainable value is understood in the construction industry as the balance between social, economic and environmental values. As Othman (2007) states, sustainable values are

1Maslow's hierarchy of needs is a theory in psychology anticipated by Abraham Maslow in his 1943 seminal contribution: "A Theory of Human Motivation". Maslow's proposed a theory that outlined five hierarchical needs which could also be applied to an organization and its employees' performance (GORDON, 1965).

2Marcus Vitruvius Pollio, architect of the first century BC, wrote "De architectura", the greatest treatise on architecture bequeathed by classical antiquity (KOTHE, 2016). 
the optimum achievement of the required functions that meets the clients' and users' needs, desires and expectations while protects the environment, enhances society and the economy.

\section{Integrating sustainability within Value Management (VM)}

VM was first introduced to examine and analyze alternative materials for selecting the one that provided the best function at the least cost (MILES, 1972). Since then, various terms have been used to describe VM, including value analysis, value engineering, value planning, value control, value methodology, value improvement, and value assurance (OKE; AIGBAVBOA, 2017a).

The term value analysis originated in the United States (PERERA; HAYLES; KERLIN, 2011) was, however, over the years, substituted by the term value engineering. The Society of American Value Engineers defines value engineering (VE) as a systematic application of techniques to identify the function of a product or service, establish the value for that function, and provide the necessary function reliably at the lowest overall cost (PIERCE et al., 1979). In the United Kingdom the term VM has been adopted to describe this process, however, some US-affiliated authors still prefer the term VE (OKE; AIGBAVBOA, 2017b).

Although the concepts VM and VE are often used for the same purpose, for simplicity, the term VM was adopted throughout this study as a systematic, multidisciplinary and structured methodology. VM identifies opportunities to remove unnecessary costs, to improve the value and optimize life cycle costs of a facility while assuring that quality, reliability, performance, and other critical factors will meet or exceed the customer's expectations (DELL'ISOLA, 1997).

The VM process consists of three distinct phases: the pre-study phase, the study or workshop phase and the post-study phase (PERERA; HAYLES; KERLIN, 2011). The second phase referred as the study or workshop phase is usually associated to as the job plan (DALLAS, 2006). According to Perera, Hayles and Kerlin (2011), the job plan comprises:

(a) pre-study phase, in which occurs the preparation for VM adoption, stakeholder identification and consultation;

(b) information phase, which involves the assimilation and analysis of information required to define the study, including, client and end user requirements;

(c) creativity stage, when creative alternative solutions and ideas are generated;

(d) judgement stage, that encompasses the evaluation of ideas generated, analysis and solutions ranking;

(e) development stage, for further development of the short-listed idea solutions into detailed workable solutions;

(f) recommendation, which refines the final recommendation to the client; and

(g) post-study stage, when the recommendations implementation determines the success or failure level.

This study comprises the information phase, which involves the identification of needs and desires of end users. The main contribution of the study is the development of a data collection instrument to identify end users' needs and values related to sustainability, hence helping to overcome a potential barrier for integrating sustainability in VM studies (Figure 1). The focus on this phase is also an attempt to facilitate users participation in the beginning of the project, since sustainability concerns should be incorporated into objectives of the project and considered by all VM team members (ABIDIN; PASQUIRE, 2007).

\section{Research method}

The investigation was carried out in four SHPs of a same developer's product family to infer the desired sustainable values from the end users' perspective. The research method was based on the concept of stated preferences (BRANDLI; HEINECK, 2004; MORIKAWA, 1989), which has been used in previous studies to investigate the concept of desired value in SHPs (GRANJA et al., 2009; KOWALTOWSKI; GRANJA, 2011; CONCEIÇÃO; IMAI; URBANO, 2015; MORAES, 2017). 
Figure 1 - Integrating sustainability in VM

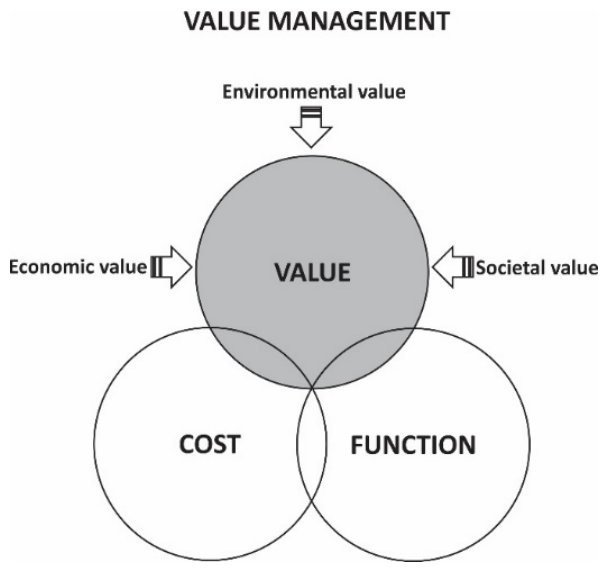

The SHPs analyzed correspond to four housing developments in the region of the city of Campinas with consists of apartments per floor, without any sustainable strategy. The project is the same for all housing developments (Minha Casa Minha Vida housing program, family income track 2), and comprises two types of apartments, with two or three bedrooms, distributed on a four-storey flat buildings. The SHPs has leisure infrastructure as party hall and sports court and in the internal area of the apartments kitchen, service area, two or three bedrooms, bathroom, living/dining room and terrace.

\section{Sample sizing}

The sample sizing followed Hair et al. (2005) and its distribution in the individual social housing projects is presented in Table 1. The research universe comprises residents from the four SHPs selected. The calculation of sample size $\mathrm{n}$ was based on the following parameters:

(a) $\mathrm{Z}=1,96$, which corresponded to the number of standard deviations of the normal distribution based on the adopted significance level of 95\%;

(b) $\mathrm{N}$, the size of the studied universe, i.e.800 housing units;

(c) $\varepsilon=7 \%$, corresponding to the maximum acceptable error estimate; and

(d) And $\mathrm{p}=50 \%$, considering that there are no estimates for the value attributes selected.

According to the parameters above, a minimum of 158 interviews were necessary for the 800-units universe considered. This study interviewed 164 owners or heads of units ${ }^{3}$, of which $75 \%$ were female, which is in line with homogeneous sampling. The sampling approach has allowed the research to gain a sharper focus and to reduce variation (PATTON, 2014).

\section{Stated preference technique}

The study employed the stated preference technique (SPT) based on Morikawa (1989). The SPT consists in presenting the interviewee with a set of hypothetical options from which the interviewee chooses one. The choice made represents the individual's preference for one attribute alternative over the others (ADAMOWICZ; LOUVIERE; WILLIAMS, 1994).

One of the advantages of using this technique in qualitative research variables such as comfort, is the ability to define variables and set up scenarios which explicitly distinguish the various situations (GALVÃO et al., 1996). The most common criticism refers to the hypothetical nature of the questions (EARNHART, 2002) and to the fact that behavior is not observed (ADAMOWICZ; LOUVIERE; WILLIAMS, 1994). To mitigate this problem, participants were asked to simulate real choices and to base their choices on their actual preferences and desires, rather than on their current situation.

${ }^{3}$ Collection of detailed personal and socioeconomic information concerning respondents was not authorized by the administration of the housing developments. 
Table 1 - Sample definition of case study on desired sustainable values in social housing projects in the region of Campinas, Brazil

\begin{tabular}{c|c|c|c}
\hline $\begin{array}{c}\text { Social housing projects } \\
\text { analysed }\end{array}$ & $\begin{array}{c}\text { Residential units in each } \\
\text { housing project }\end{array}$ & $\begin{array}{c}\text { Percentage } \\
\text { (\%) }\end{array}$ & $\begin{array}{c}\text { Number of conducted } \\
\text { interviews }\end{array}$ \\
\hline Social housing project 1 & 200 & 25 & 50 \\
Social housing project 2 & 200 & 25 & 30 \\
Social housing project 3 & 120 & 15 & 32 \\
Social housing project 4 & 280 & 35 & 52 \\
\hline Total & $\mathbf{8 0 0}$ & $\mathbf{1 0 0}$ & $\mathbf{1 6 4}$ \\
\hline
\end{tabular}

The assembly script proposed by Brandli and Heineck (2004) was adopted for the SPT application. This script consists on:

(a) identifying the most relevant attributes to be incorporated;

(b) pre-testing and application; and

(c) data analysis and interpretation.

The AQUA - HQETM rating system was adopted as the reference for sustainable values attributes. AQUA $\mathrm{HQE}^{\mathrm{TM}}$ is a French rating tool that leads to certification levels according with environmental issues considered in the construction of a building (YUSOFF; WEN, 2014). This choice emerged because, distinctively from most certification schemes, which evaluate sustainability based on the sum of achieved credits chosen by the entrepreneur, in the AQUA - HQETM system all the credits must be attended to a greater or lesser degree. This leads to synergic effects among the sustainable attributes. This flexibility, coupled with the attention delivered to all project items - not just the low-cost ones -, allow for a fairer evaluation and inhibit greenwashing.

After identifying sustainable value attributes and designing the cards, an online pre-test was carried out by professionals and non-experts who are not part of the final study's sample, to evaluate the ease of understanding of the data collection instrument used and to assess its potential to avoid bias in relation to user's judgement. In this phase, some adjustments were made in the cards description to simplify and facilitate their understanding. Some graphical adaptations were needed for the cards concerning aspects the respondents could be not fully familiar with, such as environmental practices in the construction phase. This pre-test proved to be effective, since the respondents were later able to understand the purpose of the study without the interference or help of the researchers.

\section{Data collection}

The illustrated cards ${ }^{4}$ (Figure 2) developed for data collection were divided into four key value areas (suits/categories): environment, energy and savings, indoor comfort, and health and safety (Table 2). The health and safety category received four value items, while the remaining categories received five items, to sum a total of nineteen illustrated cards.

The study consisted in asking respondents about their preferences relatively to sustainable strategies in SHPs. Data collection was always performed in the afternoon, from June to August of 2017. Respondents were individually interviewed in their homes by a single researcher, using a single set of illustrated cards and data sheets for registering their preferences. Initially, the researcher informed the interviewee about the purpose of the research and about the application of the illustrated cards. Subsequently, the interviewee was asked to rank his/her preferences considering his/her desires and priorities. All respondents demonstrated ability to understand the cards and rank their priorities without the need for interference from the researcher.

In the first round, the interviewees were asked to hierarchize the desired sustainable values of each suit (category) of cards. This was registered on a data sheet by the researcher and then a further round was carried out to select only the first choices (priorities) of each category. Finally, in the last cycle, the interviewee was asked to rank the four remaining priority choices, one of each categories, chosen in the previous cycle, so to have the first choice of each category according to the interviewee's preference.

${ }^{4}$ The illustrations used for the development of the cards were drawn up by the authors from free vectors and icons available at: https:// www. freepik. com/. 
Figure 2 - Card game tool (set of 19 cards distributed in 4 suits - categories) used as a research instrument to infer the green desired values from the end-user's perspective
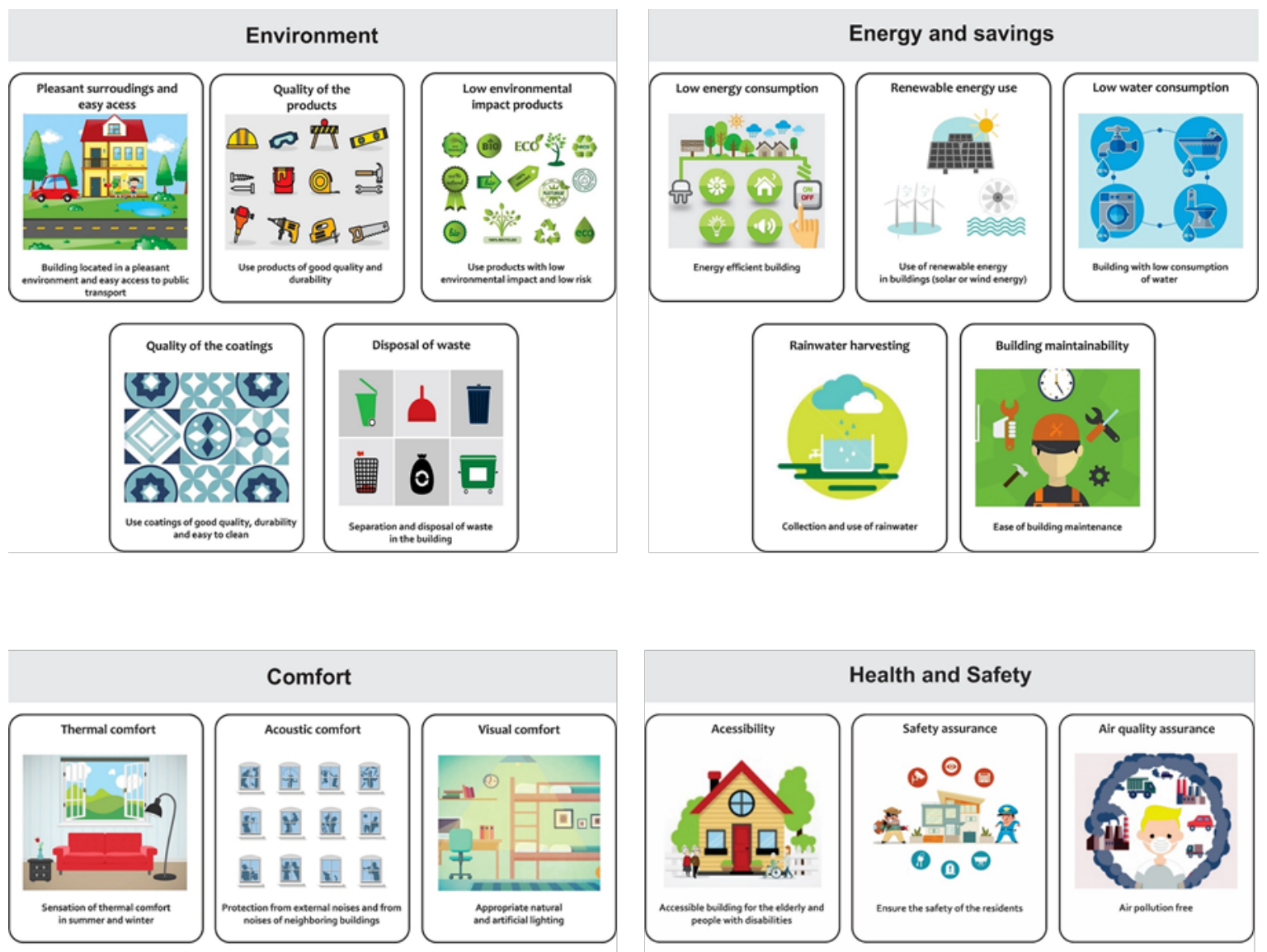

\section{Comfort}

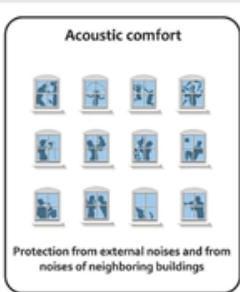

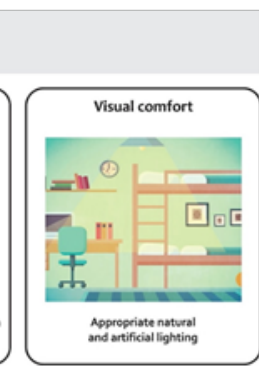
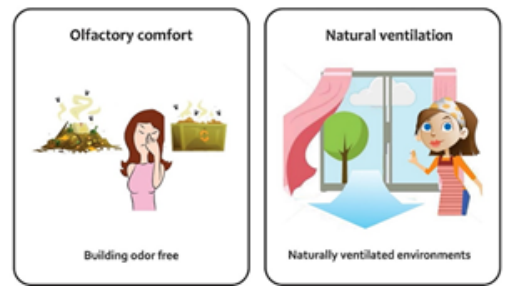

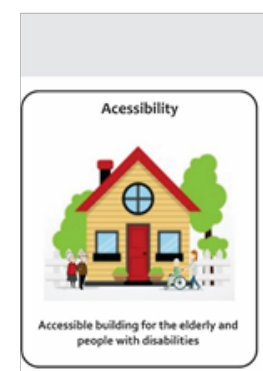

Health and Safety
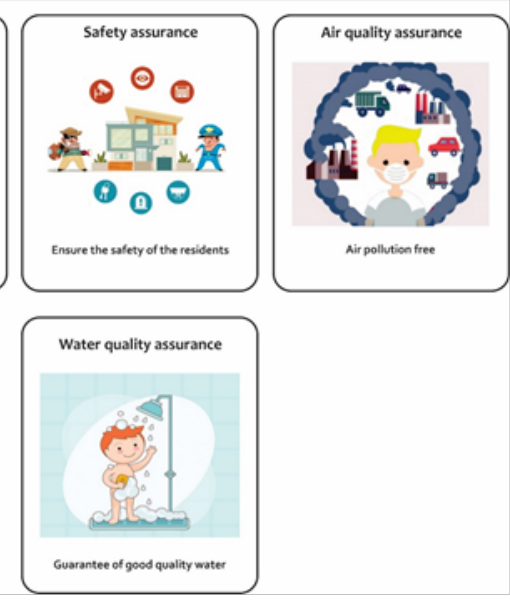

\section{Data analysis}

Bootstrap confidence intervals with Bonferroni correction were used to evaluate the importance of the items within each category. The bootstrap consists of a non-parametric technique that performs the repetition of the experiment with replacement (JONES, 2011). Thus, from the original sample, new random samples are obtained, and the estimates recalculated. Confidence intervals are constructed from these new estimates. This technique is adequate when the actual distribution of the sample data is unknown, as in this case.

To measure the importance of each card within its respective category, a variable called Index of General Significance (IGS) was used (GRANJA et al., 2009). This index was established based on the frequency with which the cards of value into their suits were selected as first, second, third, fourth and fifth options by the respondents. Since the Health and Safety suit category only has four cards, the factors were weighted for consistency relatively to the five-card suits.

\section{Results and discussion}

The attributes hierarchy selected by the respondents, given by the IGI, indicates how the values should be prioritized during the design process for best adherence to the users' expectations. Figure 3 presents the value 
hierarchy chosen by the respondents. From the 19 value attributes analyzed, the residents valued water quality, safety and air quality assurance, and accessibility the most.

These results corroborate some observations of previous studies conducted in the same region (GRANJA et al., 2009; KOWALTOWSKI; GRANJA, 2011; MORAES, 2017). Although these previous studies did not evaluate the specific values regarding sustainability, SHPs residents highly value their safety. According to Kowaltowski et al. (2006), results from a post-occupancy-evaluation study showed that the respondents presented positive opinions about the residential unit, but were dissatisfied with the external environment and vicinity of the housing complex. Indeed, in the present study, the item "safety" ranked second among the 19 analyzed items, even though the sample location was characterized by a low level of violence. This may reflect the constant need to feel safe in a society with high crime rates, which may introduce some perception bias (KOWALTOWSKI et al., 2006).

Table 2 - The content of the 19 sustainable design values used in the case study

\begin{tabular}{c|c|c}
\hline Categories (suits) & Card & Green desired values \\
\hline \multirow{4}{*}{ Environment } & 1 & Pleasant surroundings and easy access \\
\cline { 2 - 3 } & 2 & Quality of the products \\
\cline { 2 - 3 } & 3 & Low environmental impact products \\
\cline { 2 - 3 } & 4 & Quality of the coatings \\
\hline \multirow{5}{*}{ Energy and savings } & 5 & Disposal of waste \\
\cline { 2 - 3 } & 6 & Low energy consumption \\
\cline { 2 - 3 } & 7 & Renewable energy use \\
\cline { 2 - 3 } & 9 & Low water consumption \\
\hline \multirow{5}{*}{ Comfort } & 10 & Rainwater harvesting \\
\cline { 2 - 3 } & 11 & Building maintainability \\
\cline { 2 - 3 } & 12 & Thermal comfort \\
\cline { 2 - 3 } & 13 & Acoustic comfort \\
\cline { 2 - 3 } & 14 & Visual Comfort \\
\hline \multirow{5}{*}{ Health and safety } & 15 & Olfactory comfort \\
\cline { 2 - 3 } & 16 & Natural ventilation \\
\cline { 2 - 3 } & 17 & Accessibility \\
\cline { 2 - 3 } & 18 & Safety assurance \\
\hline
\end{tabular}


Figure 3- General results of the case of study on sustainable desired values Key value areas (categories) and green desired values

\author{
Index of General Significance (IGS)
}

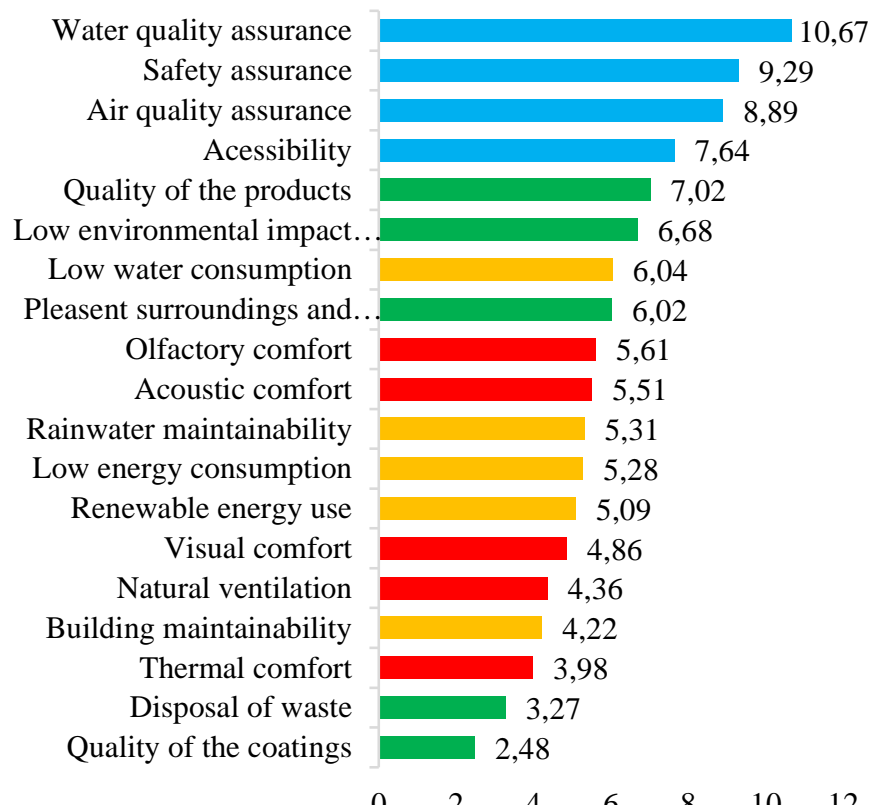

\title{
Health and \\ Environment \\ Energy and
}

Evidences also show that users value water condition more than safety (Figure 3). A possible explanation about the importance assigned by respondents to water quality is that water is essential for their living, while safety could be more easily managed (BENEDIKT, 2008; LIMA et al., 2019). Another reason for the concern with water quality could be related to the quality of the water received by the residents. Water delivery systems in the case study region have been recently criticized both in qualitative and quantitative terms due to the great water demand and the amount of organic discharge into water bodies (SUSTAINABLE..., 2015). It is also important to mention that data collection was carried out over a water shortage period in the region, which may have contributed to increase the respondents' concern about this topic.

Another interesting perception in relation to water is that the users emphasized its own quality over the relevance of savings and water consumption habits. The category of energy and savings (in yellow) when related to sustainable values is not the highest priority for respondents. However, it is interesting to note that from previous studies (GRANJA et al., 2009, KOWALTOWSKI; GRANJA, 2011; MORAES, 2017), the results pointed out that the running costs represent a significant concern for low income families.

Health and Safety is the most valued category (suit) by the respondents (Figure 3). Although the respondents did not mention any specific reason for this choice, these attributes might have been more valued because they could be associated with basic survival conditions (BENEDIKT, 2008). The reason that seems to have led most families to identify accessibility (4th position) as an important attribute relates to their desire for an elevator, which hinders residents' everyday access as well as for the elderly and people with disabilities, as this equipment is not mandatory for buildings with up to 4 floors. This configuration is widely used for being the limit for vertical SHPs from the cost perspective.

Surprisingly the respondents did not show a significant concern regarding thermal comfort. This is probably because the survey was conducted during the coolest months of the year. Another factor that may have contributed is the way the buildings were implemented. However, it is not possible to identify a pattern, since the 40 towers of the sample followed various solar orientations.

Figure 4 shows the bootstrap confidence intervals. The range of possible comparisons is $\mathrm{c}=10$ for the 5 -card suits Environment, Energy and savings and Indoor comfort, and c $=6$ for the 4-card suit Health and safety. For the 19 cards, a total of 171 pairwise comparisons were possible. 
Figure 4 highlights three groups. First, the top 4 aspects (water quality, safety assurance, air quality assurance and accessibility) reflect the respondents' highest priorities and a contrasting variance profile from the large group of 10 items which shows similar preference ranges (between 20-30\%), as well as from the bottom 5 items showing little variance but also low priority from the user's perspective (between 10 and 20\%). The discrete variation of preference ranges for the large mid group suggests that respondents may not be sufficiently informed about the assessed items, or that they can simply not differentiate their priorities regarding these subjects.

The Environmental attributes appeared next in respondent's valuation: quality of products and low environmental impact products $\left(5^{\text {th }}\right.$ and $6^{\text {th }}$ positions, box in Figure 3$)$. As per Maslow's hierarchy of needs and Benedikt (2008) building environment needs one would expect that concerns reagarding Health and Safety related valuations would come first, followed by Comfort and only then environment aspects, such as efficient resourse use. The research shows, however, that, when all attributes are simultaneously compared, users valued the Environment category more than comfort and savings aspects, which suggests some awareness and concern about the impact of the building on the environment. The remaining environmental attributes (waste disposal and quality of coating) showed up as the lowest ranked ones in the value hierarchy. This may suggest that respondents perceive those attributes at low priority that can be more easily adjusted, without the need for great interference.

These results reveal opportunities to improve decision-making processes in product development and in design process management. By establishing the hierarchy of customers' values, architects and planners can best drive the scarce financial resources flow in achieving the target costs. A key message from Figure 4 is that the design team and the developer could think of reallocating financial resources originally assigned to other items up to the highly valued 4 items. Additional opportunities for green premium reduction are to review the cost structure of the conventional buildings (GRANJA et al., 2009) to seek further cost reallocation.

Figure 4 - Results of the case study on desired values in SHPs, using bootstrap confidence values related to the Index of General Significance (IGS)

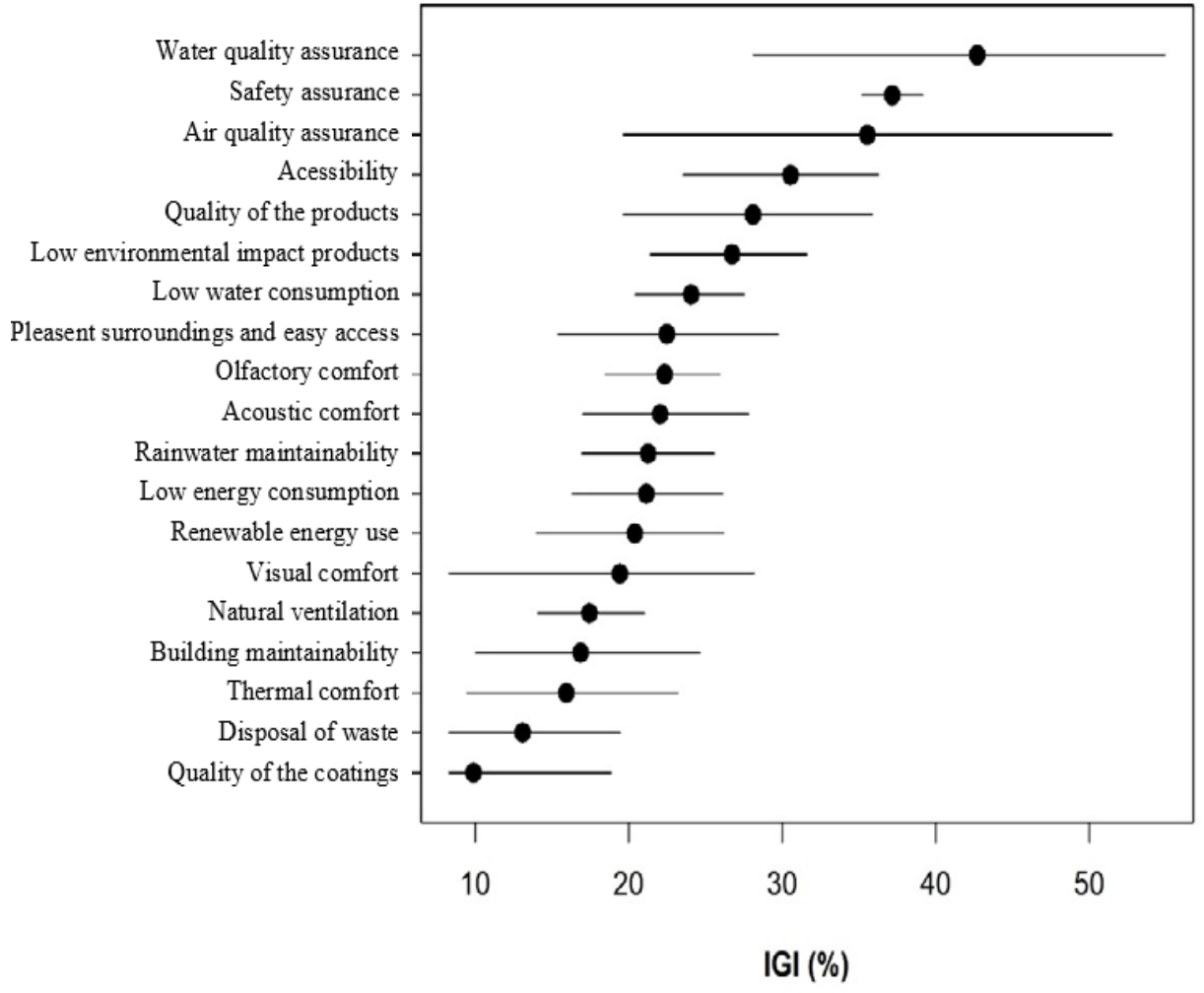




\section{Conclusions}

An investigation of sustainable desired values in the built environment was presented as a case study conducted in four SHPs in the region of Campinas, in the State of São Paulo, Brazil. This study employed the stated preference technique using a set of illustrated cards to identify end users’ preferences.

Prior work has already documented the introduction of the concept of desired values as an important tool to assess building performance and improve the design and production process in social housing. Nevertheless, the scarcity of literature indicates that the identification of the end user's preferences in relation to sustainability has not been expressly appreciated or remains an untapped research area. To our knowledge, this is the first study to investigate the desired values regarding sustainability based on the AQUA - HQETM rating system.

The tool has proved to be instrumental for understanding the sustainable strategies should be prioritized for project alignment with end user values. The results hierarchically ordered respondents answers and showed that they valued health and safety attributes the most, particularly water quality. Environment category's attributes were ranked next, which demonstrates some awareness and concern about the environmental impact of the building.

The results somehow reinforce the concept that satisfaction begins with meeting basic needs, confirm previous studies' findings and suggest its validity to the scope of sustainability. Despite this, some limitations are worth noting. The selected sample represents a group of people with a specific income, located in a specific region, and residing in SHPs pertaining to the same product family of a given developer. The results can be generalized for housing projects within these strata but would otherwise require further research for validating our findings in other geographic and income and product contexts. The similar preference variation ranges for the large mid group of attributes suggest that respondents may be either insufficiently informed about the assessed items, or simply bear similar priorities regarding several subjects. Further applications with more detailed explanation on sustainable values and the meaning conveyed by each card might help to minimize ignorancedriven bias.

Nonetheless, this study results reveal opportunities to improve decision-making processes in product development and in design process management. By establishing the hierarchy of customers' values, architects and planners can best drive the scarce financial resources flow in achieving the target costs. As the 'green premium' is reduced, delivering sustainable value becomes more feasible from the housing developers' perspective, and helps to close the cycle to finally propel its quotidian implementation in real-life.

\section{References}

ABIDIN, N. Z.; PASQUIRE, C. L. Delivering sustainability through value management. Engineering, Construction and Architectural Management, v. 12, n. 2, p. 168-180, 2005.

ABIDIN, N. Z.; PASQUIRE, C. L. Revolutionize value management: a mode towards sustainability. International Journal of Project Management, v. 25, n. 3, p. 275-282, 2007.

ADAMOWICZ, W.; LOUVIERE, J.; WILLIAMS, M. Combining revealed and stated preference methods for valuing environmental amenities. Journal of Environmental Economics and Management, v. 26, p. 2271-292, 1994.

AL-YAMI, A. M. H.; PRICE, A. D. F. Exploring conceptual linkage between value engineering and sustainable construction. In: ANNUAL ARCOM CONFERENCE, 21., London, 2005. Proceedings [...] London: Associantion of Researchers in Construction Management, 2005.

BENEDIKT, M. L. Human needs and how architecture addresses them. University of Texas Press, 2008.

BOZTEPE, S. User value: competing theories and models. International Journal of Design, v. 1, n. 2, p. 55-63, 2007a.

BOZTEPE, S. Toward a framework of product development for global markets: a uservalue-based approach. Design Studies, v. 28, n. 5, p. 513-533, 2007b.

BRANDLI, L. L.; HEINECK, L. F. M. Uma experiência sobre o uso da técnica de preferência declarada. In: ENCONTRO NACIONAL DE TECNOLOGIA DO AMBIENTE CONSTRUÍDO, São Paulo, 2004. Anais [...] São Paulo: ANTAC, 2004. 
CARMONA, M. Housing design quality: through policy, guidance and review. London: Taylor \& Francis, 2001.

SUSTAINABLE COUNCIL FOR SUSTAINABLE CONSTRUCTION. Aspects of sustainable construction in Brazil and public policy promotion. 2015.

CONCEIÇÃO, P.; IMAI, C.; URBANO, M. Captura e hierarquização de requisitos do cliente de habitação social a partir da avaliação pós-ocupação e da técnica de preferência declarada. Gestão \& Tecnologia De Projetos, v. 10, n. 1, p. 83-102, 2015.

CONNAUGHTON, J.; GREEN, S. Value Management in construction: a client's guide. Construction Industry Research \& Information Association, 1996.

DALLAS, M. F. Value and risk management a guide to best practice. oxford: Blackwell, 2006.

DELL’ISOLA, A. J. Value engineering: practical applications for design, construction, maintenance \& operations. R.S. Means Co, 1997.

EARNHART, D. Combining revealed and stated data to examine housing decisions using discrete choice analysis. Journal of Urban Economics, v. 51, n. 1, p. 143-169, 2002.

GALVÃO, A. et al. Técnicas de preferência declarada na análise do nível de serviço hoteleiro. Gestão \& Produção, v. 3, n. 2, p. 188-203, 1996.

GORDON, G. G. The relationship of satisfiers and dissatisfiers to productivity, turnover and morale. American Psychologist, v. 20, p. 499-502, 1965.

GRANJA, A. D. et al. A natureza do valor desejado na habitação social. Ambiente Construído, Porto Alegre, v. 9, n. 2, p. 87-103, abr./jun. 2009.

HAIR, J. F. et al. Multivariate data analysis: 6th (sixth) edition. New Jersey: Prentice Hall, 2005.

HAYLES, C. The role of value management in the construction of sustainable communities. The Value Manager, v. 10, n. 1, p. 15-20, 2004.

HERSHBERGER, R. G. Architectural programming and predesign manager. New York: McGraw-Hill, 1999.

IKEDA, A. A.; VELUDO-DE-OLIVEIRA, T. M. O conceito de valor para o cliente: definições e implicações gerenciais em marketing. Revista Eletrônica de Administração, v. 11, n. 2, p. 1-22, 2005.

JENSEN, P. A.; MASLESA, E. Value based building renovation: a tool for decisionmaking and evaluation. Building and Environment, v. 92, p. 1-9, 2015.

JONES, D. K. Diffusion MRI : theory, methods, and applications. London: Oxford University Press, 2011.

KARUNASENA, G.; RATHNAYAKE, R. M.; SENARATHNE, D. Integrating sustainability concepts and value planning for sustainable construction. Built Environment Project and Asset Management, v. 6, n. 2, p. 125-138, 2016.

KEEPING, M. What about demand? Do investors want green buildings? In: RICS RESEARCH FOUNDATION, London, 2000. Proceedings [...] London, 2000.

KELLY, J.; MALE, S.; GRAHAM, D. Value management of construction projects. $2^{\text {nd }}$. ed. New York: Wiley-Blackwell, 2014.

KOTHE, F. R. Vitrúvio revisto. Revista Estética e Semiótica, v. 6, n. 1, p. 123-150, 2016.

KOWALTOWSKI, D. C. C. K. et al. Quality of life and sustainability issues as seen by the population of low-income housing in the region of Campinas, Brazil. Habitat International, v. 30, n. 4, p. 1100-1114, 2006.

LIMA, L. P. et al. Perceived value in social housing projects. In: ANNUAL CONFERENCE OF THE INTERNATIONAL GROUP FOR LEAN CONSTRUCTION, 17., Taipei, 2009. Proceedings [...] Taipei: IGLC, 2009.

MACMILLAN, S. The value handbook: getting the most from your buildings and spaces. London: Commission for Architecture and the Built Environment, 2006. 
MANOLIADIS, O. Sustainability issues as applied to the value management practices in construction projects. In: INTERNATIONAL CONFERENCE ON SUSTAINABLE DESIGN, ENGINEERING, AND CONSTRUCTION, Reston, 2012. Proceedings [...] Reston: American Society of Civil Engineers, 2012.

MILES, L. D. Techniques for value analysis and engineering. $2^{\text {nd. }}$ ed. New York: McGraw-Hill, 1972. MIRON, L. I. G. Gerenciamento dos requisitos dos clientes de empreendimentos habitacionais de interesse social : proposta para o Programa Integrado Entrada da Cidade em Porto Alegre/RS. Porto Alegre, 2008. 351 f. Tese (Doutorado em Engenharia Civil) - Programa de Pós-Graduação em Engenharia Civil, Universidade Federal do Rio Grande do Sul, 2008.

MOGHIMI, V.; JUSAN, M. B. M.; IZADPANAHI, P. Iranian household values and perception with respect to housing attributes. Habitat International, v. 56, p. 74-83, 2016.

MORAES, A. F. S. Realocação de custos para o aumento do valor entregue no desenvolvimento de produtos residenciais. Campinas, 2017. 194 f. Dissertação (Mestrado em Engenharia Civil) - Faculdade de Engenharia Civil, Arquitetura e Urbanismo, Universidade Estadual de Campinas, Campinas, 2017.

MORIKAWA, T. Incorporating stated preference data in travel demand analysis. MIT, 1989.

NOVAK, V. M. Value paradigm: revealing synergy between lean and sustainability. In: ANNUAL CONFERENCE OF THE INTERNATIONAL GROUP FOR LEAN CONSTRUCTION, 20., San Diego, 2012. Proceedings [...] San Diego, 2012.

OKE, A. E.; AIGBAVBOA, C. O. The concept of value management. In: Sustainable value management for construction projects. Cham: Springer International Publishing, 2017a.

OKE, A. E.; AIGBAVBOA, C. O. Sustainable value management for construction projects. Cham: Springer International Publishing, 2017b.

OTHMAN, A. A. E. Generating sustainable values and achieving client satisfaction in construction projects through maintenance management: the case of housing projects in Abu Dhabi, United Arab Emirates.

Architectural Engineering and Design Management, v. 3, n. 3, p. 145-159, 2007.

PASQUIRE, C.; SALVATIERRA-GARRIDO, J. Introducing the concept of first and last value to aid lean design: learning from social housing projects in Chile. Architectural Engineering and Design Management, v. 7, n. 2, p. 128-138, 2011.

PATTON, M.Q. Qualitative research \& evaluation methods: integrating theory and practice. $4^{\text {th }}$. ed. Thousand Oaks: SAGE Publications, 2014.

PERERA, S.; HAYLES, C. S.; KERLIN, S. An analysis of value management in practice: the case of Northern Ireland's construction industry. Journal of Financial Management of Property and Construction, v. 16, n. 2, p. 94-110, 2011.

PÉREZ-LOMBARD, L.; ORTIZ, J.; POUT, C. A review on buildings energy consumption information. Energy and Buildings, v. 40, n. 3, p. 394-398, 2008.

PIERCE, J. L. et al. Guidelines for Value Engineering (VE). Value world, Texas, v. 6, n. 2, 1979.

RICHINS, M. L. Valuing things: the public and private meaning of possessions. Journal of Consumer Research, v. 21, p. 504-521, 1994.

SALIBA, M.; FISHER, C. Managing customer value: a framework allows organisatioins to achieve and sustain competitive advantage. Quality Progress, v. 33, n. 6, p. 63-69, 2000.

SALVATIERRA-GARRIDO, J.; PASQUIRE, C.; THORPE, T. Critical review of the concept of value in lean construction theory. In: ANNUAL CONFERENCE OF THE INTERNATIONAL GROUP FOR LEAN CONSTRUCTION, 18., Haifa, 2010. Proceedings [...] Haifa, 2010.

SAXON, R. Be valuable: a guide to creating value in the built environment. London: Constructing Excellence, 2005.

SPITEN, T. K. et al. Enhancing value for end users: a case study of end-user involvement. In: ANNUAL CONFERENCE OF THE INTERNATIONAL GROUP FOR LEAN CONSTRUCTION, 24., Boston, 2016. Proceedings [...] Boston, 2016.

THOMSON, D. S. et al. Managing value and quality in design. Building Research \& Information, v. 31, n. 5, p. 334-345, 2003. 
UNITED NATIONS ENVIRONMENT PROOGRAMME; SUSTAINABLE BUILDINGS AND CLIMATE INITIATIVE. Buildings and climate change. Paris, 2009.

WORLD COMMISSION ON ENVIRONMENT AND DEVELOPMENT. Our common future: the world commission on environment and development. Oxford: Oxford University Press, 1987.

WOODRUFF, R. B. Customer value: the next source for competitive advantage. Academy of Marketing Science. Journal; Spring, v. 25, n. 2, p. 139-153, 1997.

YUSOFF, W. Z. W.; WEN, W. R. Analysis of the International Sustainable Building Rating Systems (SBRSs) for Sustainable Development with Special Focused on Green Building Index (GBI) Malaysia view project Developing Corporate Waqf Framework for Malaysia View project Analysis of the In. Journal of Environmental Conservation Research, v. 2, n. 1, p. 11-26, 2014.

Adrieli Cristina Vieira de Carvalho

Departamento de Arquitetura e Construção | Universidade Estadual de Campinas | Av. Albert Einsten, 951, Cidade Universitária Zeferino Vaz| Barão Geraldo Campinas - SP - Brasil | CEP 13083-852 | Tel.: (19) 3788-2082 | E-mail: adrieli.cv.carvalho@gmail.com

Ariovaldo Denis Granja

Departamento de Arquitetura e Construção | Universidade Estadual de Campinas | E-mail: adgranja@fec.unicamp.br

Vanessa Gomes da Silva

Departamento de Arquitetura e Construção | Universidade Estadual de Campinas | E-mail: vangomes@fec.unicamp.br

\section{Ambiente Construído}

Revista da Associação Nacional de Tecnologia do Ambiente Construído

Av. Osvaldo Aranha, 99 - 3o andar, Centro

Porto Alegre - RS - Brasil

CEP 90035-190

Telefone: +55 (51) 3308-4084

Fax: +55 (51) 3308-4054

www. seer. ufrgs. br/ ambienteconstruido

E-mail: ambienteconstruido@ufrgs.br 